\title{
Natrium Alginat Sebagai Polimer Mukoadhesif Terhadap Daya Lekat Serta Pelepasan Granul Mukoadhesif Amoksisilin
}

\author{
(Sodium Alginat as A Mucoadhesive Polymer to Adhesion \\ Strength and Amoxicillin Mucoadhesion Granul Release)
}

\author{
YUDI SRIFIANA*, ARI WIDAYANTI, NOPRIADI \\ *Fakultas Farmasi dan Sains Universitas Muhammadiyah Prof. DR. HAMKA
}

Diterima 2 Januari 2019, Disetujui 22 Maret 2019

\begin{abstract}
Abstrak: Mukoadhesif merupakan bentuk sediaan bioadhesif yang membentuk ikatan dengan membran mukosa. Sediaan mukoadhesif bertahan pada mukosa dalam periode waktu yang diperlama sehingga dapat meningkatkan ketersediaan hayati obat. Penelitian ini bertujuan untuk mengetahui pengaruh penggunaan natrium alginat sebagai polimer bioadhesif terhadap daya lekat sediaan. Granul mukoadhesif dibuat menggunakan amoksisilin sebagai model zat aktif dan natrium alginat sebagai polimer bioadhesif dengan metode granulasi basah. Evaluasi granul yang dilakukan yaitu uji susut pengeringan, uji distribusi ukuran partikel, uji wash off menggunakan mukosa lambung tikus dan uji disolusi. Hasil perolehan kembali F1, F2, F3, F4, F5, $540 \mathrm{mg}, 560 \mathrm{mg}, 580 \mathrm{mg}, 600 \mathrm{mg}, 620 \mathrm{mg}$. Hasil uji sifat alir 10,78-11,75 g/detik dan sudut diam 33,50-35,15 , hasil uji distribusi ukuran patikel berada pada rentang 1410-1680 $\mu \mathrm{m}$, susut pengeringan 11,07-13,57\%, uji wash off F1, F2, F3, F4, dan F5 yaitu 12,67, 14,00, 18,67, 26,00, dan 33,33\%. Uji anova 2 arah terhadap \% terdisolusi dan hasil uji wash off menghasilkan nilai sig. $<0,05$, sehingga terdapat perbedaan bermakna antar formula. Berdasarkan hasil yang diperoleh dapat disimpulkan bahwa peningkatan konsentrasi natrium alginat dapat meningkatkan daya mukoadhesif granul amoksisilin pada mukosa lambung tikus tetapi kurang dapat menahan pelepasan obat, dan formula yang paling baik adalah formula 3 yang mengandung natrium alginat $580 \mathrm{mg}$.
\end{abstract}

Kata kunci: Natrium alginat, polimer bioadhesif, granul mukoadhesif.

\begin{abstract}
Mucoadhesive is a bioadhesive dosage form which forms a bond with mucous membranes. Mucoadhesive dosage forms stayed on mucous membranes in prolonged time so can increase bioavailability. This study intended to determine the effect of sodium alginate as bioadhesive polymer to mucoadhesive strength of granules. The granules prepared using amoxicillin as active agent and sodium alginate as bioadhesive polymer by wet granulation method. Granule evaluation are moisture content, particle size, wash off test using rat stomach and dissolution test. Test results of total recovery F1, F2, F3, F4, F5, $540 \mathrm{mg}, 560 \mathrm{mg}, 580 \mathrm{mg}, 600 \mathrm{mg}, 620 \mathrm{mg}$. Test results of flow rate 10,78-11,75 g/ second, and angle of repose $33,50-35,15^{\circ}$, test of particle size distribution in the range of $1410-1680$ $\mu \mathrm{m}$, moisture content from 11.07 to $13.57 \%$, wash off test of F1, F2, F3, F4 and F5 as consecutively 12.67, 14.00, 18.67, 26.00 and 33.33\%. 2-way ANOVA test to \% dissolution and wash-off test results sig. $<0.05$, so there is a significant difference between formulas. Based on the results showed that increasing concentration of sodium alginate increase mucoadhesive strength of granules but less able to resist of drug release, and the best formula is F3 that containing sodium alginate $580 \mathrm{mg}$.
\end{abstract}

Keywords: Sodium alginate, bioadhesive polymer, mucoadhesive granules. 


\section{PENDAHULUAN}

ANTIBIOTIK golongan beta laktam mempunyai sifat farmakodinamik nonconcentration-dependent dan memiliki jendela absorbsi sempit pada bagian atas usus halus(1). Amoksisilin merupakan salah satu antibiotik golongan $\beta$-laktam dan berspekrum luas, memiliki waktu paruh sekitar 1-1,5 jam(2). Amoksisilin merupakan antibiotik lini pertama untuk infeksi Helicobacter pylori yang merupakan mikroba anaerob penyebab pada hampir $90 \%$ kasus ulkus peptikum(3). Amoksisilin sebagai obat terapi untuk H. pylori harus memiliki konsentrasi yang efektif dan tinggal dalam waktu yang lama di dalam lambung. Dengan cara melokalisasi sistem penghantaran obat pada lambung diharapkan dapat meningkatkan jumlah obat yang diabsorbsi sehingga meningkatkan efektivitasnya dalam mengobati $H$. Pylori terkait tukak lambung. Sistem mukoadhesif tertahan di lambung merupakan salah satu alternatif untuk penghantaran amoksisilin tersebut.

Mukoadhesif merupakan bentuk sediaan bioadhesif yang membentuk ikatan dengan membran mukosa sehingga dapat meningkatkan waktu tinggal obat. Sistem ini memungkinkan waktu pelepasan dan penyerapan obat lebih lama dan konstan di tempat/ lokasi terjadinya absorpsi, sehingga ketersediaan hayati obat meningkat. Material mukoadesif kebanyakan adalah dalam bentuk sintetis, hidrofilik alami, atau polimer yang tidak larut air dan mampu membentuk sejumlah ikatan hidrogen karena adanya gugus karboksil, sulfat atau gugus hidroksi. Polimer sintetis misalnya karbomer, hidroksi propil selulosa (HPC), hidroksi propil metil selulosa (HPMC), hidroksi etil selulosa dan polikarbonil. Polimer alami misalnya xantan gum, natrium alginat, gelatin, akasia, dan tragakan. Polimer bioadhesif bukan saja mampu memberikan efek adhesif tetapi juga dapat mengontrol laju pelepasan obat(4).

Penelitian yang dilakukan oleh Indrawati dkk. (2005), natrium alginat dapat digunakan sebagai polimer bioadhesif. Natrium alginat merupakan suatu polisakarida yang diperoleh dari alga coklat yang merupakan suatu kopolimer yang terdiri dari $\beta$-D asam manuronat (M) dan $\alpha(1,4)-\mathrm{L}$ asam guluronat
(G). Natrium alginat mempunyai banyak gugus karboksilat. Bahan bioadhesif yang mengandung gugus karboksilat dalam suasana asam akan menjadi bentuk asamnya yang akan membentuk ikatan hidrogen dengan asam sialat, rantai oligosakarida atau pada protein dari musin. Polimer ini juga tidak bersifat toksik, tidak memberikan reaksi alergi dan dapat terurai dalam tubuh(5). Sehingga diharapkan memberikan sifat bioadhesif yang lebih baik pada sediaan.

\section{BAHAN DAN METODE}

BAHAN. Amoksisilin trihidrat baku (Heibei zhongrun), amoksisilin trihidrat (DSM sinochem), natrium alginat (Qingdaoliyang seaweed group), laktosa (Meggle), $\mathrm{HCl}, \mathrm{NaCl} 0,9 \%$ (b/v), lambung tikus, lem sianoakrilat dan larutan lambung buatan.

Alat. Alat uji disolusi (Elektrolab), spektrofotometer UV-VIS (PG Instrumen T60), oven (Memmert), pH meter (Mettler Toledo), timbangan analitik (Mettler Toledo), alat uji wash off (Disintegration tester), ayakan nomor 14, alat uji kecepatan waktu alir, ayakan bertingkat, alat-alat bedah dan alat-alat gelas.

METODE. Formulasi granul mukoadhesif. Granul mukoadhesif dibuat dengan mencampurkan amoksisilin, laktosa dan natrium alginat secara granulasi basah dengan pembasah air (natrium alginat-air 1:1). Bahan-bahan dicampur hingga terbentuk massa yang dapat dikepal. Massa yang terbentuk dilewatkan pada ayakan mesh 14 , kemudian dikeringkan pada suhu $50^{\circ} \mathrm{C}$ selama $7 \mathrm{jam}$.

Susut pengeringan dilakukan dengan menimbang granul dalam keadaan basah, kemudian granul dikeringkan dan menimbang granul kering sampai diperoleh bobot tetap.

Sifat alir dan sudut diam. Sejumlah granul dimasukkan ke dalam corong uji waktu alir. Penutup corong dibuka sehingga granul mengalir keluar dan tertampung pada bidang datar yang dilapisi kertas grafik milimeter. Kemudian waktu alir dan sudut diam granul dicatat.

Perolehan kembali dapat diperoleh dengan cara membagi hasil penimbangan seluruh bahan yang digunakan, dengan hasil penimbangan granul yang

Tabel 1. Formula granul mukoadhesif amoksisilin

\begin{tabular}{lllllll}
\hline \multirow{2}{*}{ Bahan } & \multicolumn{7}{c}{ Jumlah (mg) } & \multirow{2}{*}{ Kegunaan } \\
\cline { 2 - 6 } & F1 & F2 & F3 & F4 & F5 & \\
\hline Amoksisilin trihidrat & 375 & 375 & 375 & 375 & 375 & Zat Aktif \\
Natrium alginat & 540 & 560 & 580 & 600 & 620 & Polimer \\
Laktosa & 8,5 & 6,5 & 4,5 & 2,5 & 0,5 & Pengisi \\
\hline
\end{tabular}


telah dikeringkan.

Distribusi ukuran partikel dilakukan menggunakan ayakan bertingkat (sieve shaker) dengan menyusun satu seri ayakan dengan nomor $12,14,16,18,20$ dan 24 secara menurun dari ukuran lubang ayakan yang paling besar. Kurang lebih 100 $\mathrm{g}$ granul ditempatkan dalam ayakan yang paling atas, kemudian mesin pengayak dijalankan dengan frekuensi $3 \mathrm{~Hz}$ selama 20 menit

Uji wash off dilakukan dengan menggunakan alat uji disintegrasi tablet. Jaringan lambung tikus yang telah dicuci dengan larutan $\mathrm{NaCl}$ fisiologis dilekatkan pada kaca objek dengan menggunakan lem sianoakrilat. Sebanyak 50 granul ditempelkan pada mukosa lambung secara merata, kemudian dimasukkan ke dalam alat uji desintegrasi. Alat digerakkan naik turun sebanyak 30 kali per menit. Medium yang digunakan adalah cairan lambung buatan dengan suhu $37 \pm 0,5^{\circ} \mathrm{C}$. Pengamatan granul yang melekat dilakukan setiap 30 menit dan dihitung setelah 2 jam.

Penetapan kadar amoksisilin menggunakan Spektrofotometer UV-VIS. Sejumlah massa granul yang setara dengan 20 tablet ditimbang, kemudian dihaluskan dan diaduk homogen. Setelah homogen, sejumlah serbuk yang setara dengan bobot rata-rata 1 tablet amoksisilin ditimbang dan dimasukkan dalam labu ukur $100 \mathrm{ml}$ kemudian dilarutkan dalam cairan lambung buatan tanpa enzim $\mathrm{pH}$ 1,2 hingga volume $100 \mathrm{ml}$. memipet 1,0 ml larutan kedalam labu ukur $100 \mathrm{ml}$ dan mencukupkan dengan medium sampai garis tanda batas. Kadar amoksisilin diukur dengan menggunakan alat spektrofotometer UV-Vis pada panjang gelombang serapan maksimum.

Penetapan profil disolusi amoksisilin dari granul. Penentuan disolusi amoksisilin dari granul dilakukan menggunakan alat disolusi tipe 1 dalam medium cairan lambung buatan $\mathrm{pH}$ 1,2 sebanyak $900 \mathrm{ml}$. Suhu diatur $37+0,5^{\circ} \mathrm{C}$ dengan kecepatan 50 putaran per menit. Sampel obat yang terlepas ke dalam medium diambil pada menit ke 5, 10, 15, $30,45,60,120,360,480$ dan 720 sebanyak 12,0 ml Setiap pengambilan sampel 12,0 $\mathrm{mL}$, diganti dengan medium yang baru dengan volume yang sama dengan yang diambil. Kadar amoksisilin yang terdisolusi ditetapkan dengan metode spektrofotometri UV-Vis.

Analisa Data. Data yang dianalisa adalah data hasil uji disolusi granul mukoadhesif amoksisilin dianalisa dengan menggunakan analisa varian dua arah. 45, 60, 120, 360, 480 dan 720 sebanyak 12,0 ml Setiap pengambilan sampel 12,0 $\mathrm{mL}$, diganti dengan medium yang baru dengan volume yang sama dengan yang diambil. Kadar amoksisilin yang terdisolusi ditetapkan dengan metode spektrofotometri UV-Vis.

\section{HASIL DAN PEMBAHASAN}

Perolehan kembali Uji perolehan kembali digunakan untuk menilai metode yang digunakan bersifat reprodusibel. Hal ini penting untuk pembuatan sediaan dalam skala besar. Granul dibuat menggunakan natrium alginat dengan beberapa konsentrasi yaitu F1 $540 \mathrm{mg}$, F2 $560 \mathrm{mg}$, F3 $580 \mathrm{mg}$, F4 $600 \mathrm{mg}$ dan F5 $620 \mathrm{mg}$. Formula 5 mempunyai perolehan kembali yang lebih besar yaitu 96,44\% dibandingkan dengan formula lain (F1, F2, F3, dan F4). Perbedaan perolehan kembali ini disebabkan oleh menempelnya granul pada alat, ayakan dan hilangnya granul pada proses pembuatan.

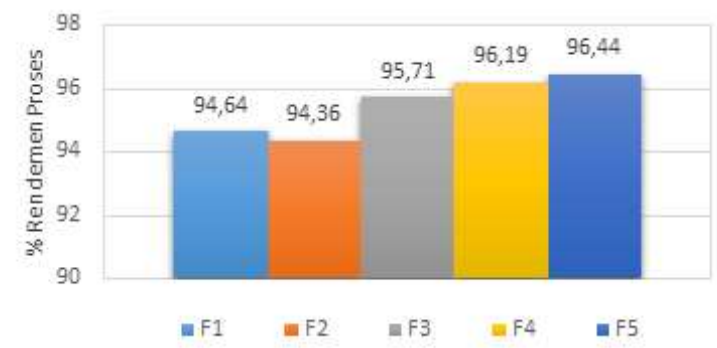

Gambar 1. Hasil perolehan kembali granul amoksisilin

Susut pengeringan. Susut pengeringan pada granul dipengaruhi jumlah air dan bahan yang mudah menguap dan hilang pada kondisi tertentu. Kandungan air yang terlalu tinggi dapat mempermudah pencemaran mikroba dan dapat menyebabkan ketidakstabilan fisik maupun kimia dari suatu sediaan farmasi. Susut pengeringan dipengaruhi oleh higroskopisitas bahan dan lamanya waktu pengeringan. Semakin lama granul dikeringkan dalam oven, semakin turun kadar airnya dan semakin tinggi nilai susut pengeringannya. Keseluruhan formula memiliki nilai susut pengeringan 11,07-13,57\%.

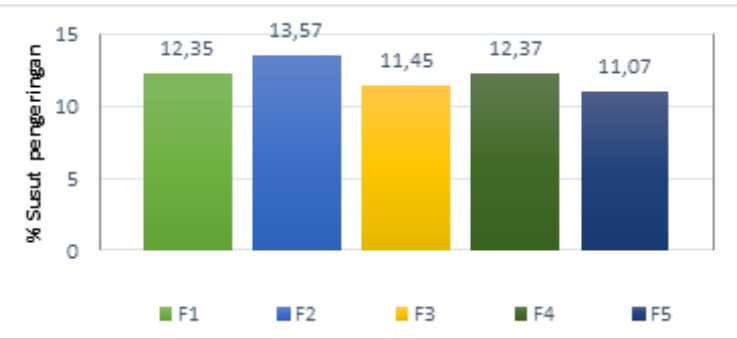

Gambar 2. Hasil susut pengeringan granul mukoadhesif amoksisilin 
Sifat alir dan sudut diam. Kemampuan granul untuk mengalir dilihat dari banyaknya granul yang mengalir tiap detik serta dari sudut baringnya. Evaluasi terhadap sifat alir dan sudut diam diperlukan untuk mengetahui sifat alir granul yang kemudian dijadikan sebagai bahan pertimbangan dalam pengemasan dan menjamin keseragaman bobot sediaan. Menurut Lachman dkk. (1994) sediaan yang memiliki sudut diam diantara 30-400 dan kecepatan alir $>10 \mathrm{~g} /$ detik menunjukkan potensial aliran yang baik(6). Formula 1 memiliki kecepatan alir yang paling baik yaitu 11,75 g/detik. Semakin meningkat konsentrasi natrium alginat semakin menurun sifat alir granul, dikarenakan terbentuknya aglomerat. Hasil uji sifat alir secara keseluruhan berkisar antara 10,78-11,75 g/ detik dan sudut diamnya berkisar antara 33,50-35,150. Berdasarkan data tersebut menunjukkan sifat mengalir yang baik.

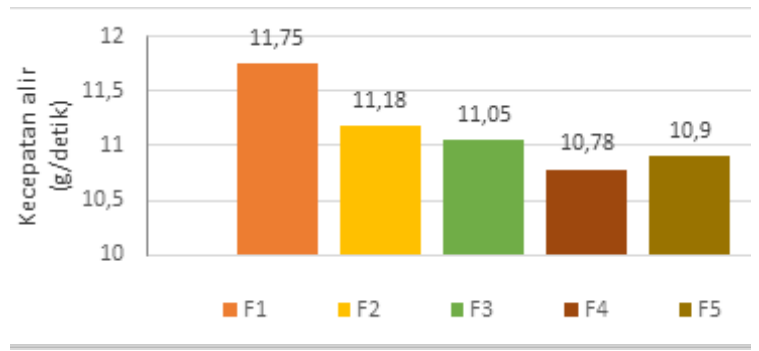

Gambar 3. Hasil sifat alir granul mukoadhesif amoksisilin

Distribusi ukuran partikel. Penentuan distribusi ukuran partikel granul dilakukan dengan metode ayakan bertingkat agar granul dapat dipisahkan berdasarkan ukurannya. Hal tersebut penting karena untuk pengujian wash off diperlukan granul dengan ukuran yang seragam agar luas permukaan granul yang berkontak dengan mukosa seragam. Formula 5 yang mengandung natrium alginat dengan konsentrasi 620 mg ukuran granulnya lebih besar pada diameter $>1680$ $\mu \mathrm{m}$ yaitu $14,4279 \%$. Hal ini dikarenakan pada formula 5 memiliki perbandingan jumlah air yang lebih besar sehingga granul yang terbentuk semakin lengket saat pengayakan dan granul saling melekat membentuk aglomerat. Dilihat dari hasil distribusi kelima formula, granul dengan ukuran 1410-1680 $\mu$ m cukup banyak dihasilkan dan cukup besar untuk diamati sehingga granul yang akan digunakan untuk uji wash off adalah granul dengan rentang ukuran 1410-1680 $\mu \mathrm{m}$.

Uji wash off. Uji wash off dilakukan pada keseluruhan formula untuk mengetahui durasi perlekatan pada mukosa lambung pada kondisi ekstrim. Hasil uji wash off semua formula menunjukkan pelekatan granul pada mukosa lambung selama 2 jam antara 12,67-33,33\%. Pengujian ini dilakukan

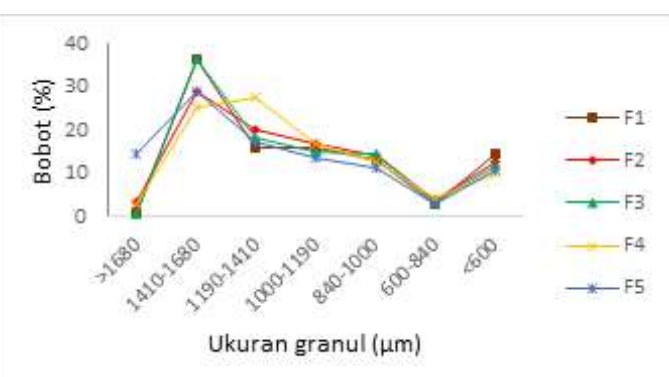

Gambar 4. Hasil pengukuran distribusi ukuran partikel granul mukoadhesif amoksisilin

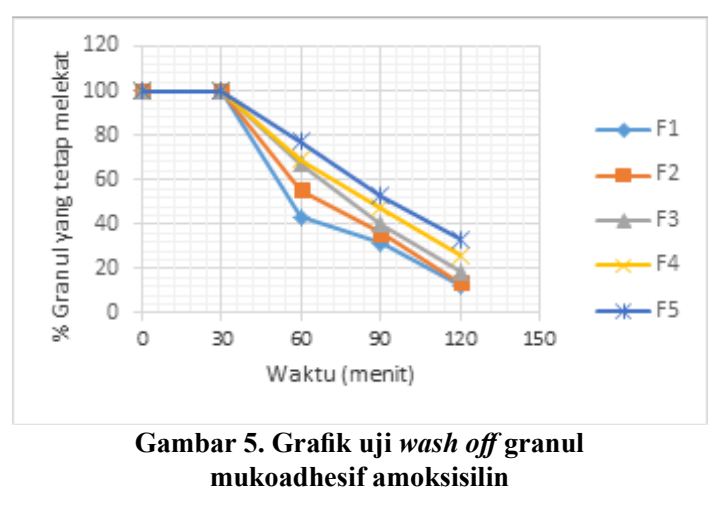

sampai waktu 2 jam, karena jika lebih dari 2 jam keutuhan jaringan mukosa sudah tidak layak lagi untuk pengujian(7). Hasil menunjukkan bahwa semakin besar konsentrasi natrium alginat yang digunakan semakin besar daya mukoadhesifnya.

Daya lekat tertinggi dimiliki oleh F5 (natrium alginat $620 \mathrm{mg}$ ) dengan persen granul yang masih tertinggal pada mukosa lambung sebesar 33,33\% setelah 2 jam. Keseluruhan formula memiliki daya lekat yang baik pada 30 menit pertama, dimana \% granul yang masih tertinggal pada mukosa lambung sebesar $100 \%$. Granul yang tertinggal pada mukosa lambung setelah 1 jam mengalami penurunan yang signifikan pada keseluruhan formula. Hal ini disebabkan oleh sifat natrium alginat yang memiliki kecepatan hidrasi yang cepat sehingga granul dapat dengan cepat mengembang (swelling) jika kontak dengan air. Daya mengembang granul yang cepat menyebabkan fisik granul secara bertahap berubah menjadi gel. Gel yang terbentuk sebenarnya masih melekat pada mukosa lambung tetapi pada uji wash off parameter yang diamati adalah jumlah granul yang masih menempel.

Penetapan kadar Amoksisilin menggunakan spektrofotometer UV-VIS. Penetapan kadar granul mukoadhesif amoksisilin menggunakan spektrofotometer UV-VIS pada panjang gelombang 229,0 nm menggunakan medium cairan lambung buatan $\mathrm{pH}$ 1,2 tanpa enzim. Kadar amoksisilin dalam 
Tabel 2. Penetapan kadar amoksisilin dalam granul mukoadhesif

\begin{tabular}{lccccc}
\hline \multicolumn{5}{c}{ \% kadar granul mukoadhesif amoksisilin } \\
\hline Formula & F1 & F2 & F3 & F4 & F5 \\
\hline Kadar (\%) & $90,69 \pm 1,04$ & $82,58 \pm 0,91$ & $98,39 \pm 1,19$ & $89,86 \pm 2,90$ & $93,50 \pm 1,35$ \\
Kadar (mg) & $340,08 \pm 3,91$ & $309,66 \pm 3,41$ & $368,72 \pm 4,34$ & $336,81 \pm 10,10$ & $350,08 \pm 4,92$ \\
\hline
\end{tabular}

granul secara keseluruhan berkisar antara 82,5898,33\%. Persyaratan kadar kapsul amoksisilin dari FI ed IV yaitu antara 90-120\%. Kadar kelima formula granul mukoadhesif amoksisilin jika dibandingkan persyaratan kadar kapsul amoksisilin yang memenuhi persyaratan adalah F1, F3 dan F5 dimana kadar masing-masing adalah 90,69, 98,39 dan 93,50\%. Dapat disimpulkan bahwa metode granulasi basah dapat digunakan dalam formulasi granul mukoadhesif amoksisilin.

Penetapan profil disolusi amoksisilin dari granul. Pada sediaan dengan pelepasan dimodifikasi, terdapat aturan untuk menyatakan jumlah obat terlarut dengan penggunaan sediaan suatu obat yang dihubungkan dengan frekuensi atau interval pemberian obat, yaitu seperti ditunjukkan pada tabel 3. Hasil uji disolusi granul mukoadhesif amoksisilin selama 12 jam berturut-turut dari F1, F2, F3, F4 dan F5 adalah $80,36,85,35,74,66,79,78$ dan 72,21\%. Berdasarkan ketentuan yang telah dijelaskan oleh Banakar (1992) mengenai aturan untuk menaksir penggunaan suatu sediaan obat berdasarkan jumlah obat yang terdisolusi

Tabel 3. Syarat obat terlarut untuk sediaan lepas terkendali untuk sediaan lepas terkendali(8)

\begin{tabular}{|c|c|}
\hline $\mathbf{Q}$ & Persen obat terlarut \\
\hline$Q_{0,25}$ & $20-45 \%$ \\
\hline $\mathrm{Q}_{0,5}$ & $46-75 \%$ \\
\hline$Q_{1}$ & $>75 \%$ \\
\hline
\end{tabular}

pada waktu tertentu. Untuk granul F1, F2, dan F4 pelepasan obat pada jam ke 12 (720 menit) memenuhi syarat Q0,5 yang memiliki range 46-75\%. Jika dilihat hasil disolusi dari F1, F2 dan F4, F2 memiliki persen disolusi yang paling besar karena granul pada F2 masih memiliki kandungan air yang cukup tinggi dibandingkan F1 dan F4 yang dapat dilihat dari hasil susut pengeringannya. Dengan demikian formula granul F1, F2 dan F5 dapat digunakan untuk sediaan lepas terkendali selama 12 jam. Pada F3 dan F5 pelepasan obat memenuhi persyaratan Q1 sehingga dapat digunakan untuk sediaan lepas terkendali selama 24 jam.

Pelepasan amoksisilin dari granul mukoadhesif. Profil pelepasan amoksisilin dari granul mukoadhesif amoksisilin mendekati model higuchi karena menghasilkan garis lurus dengan nilai koefisien korelasinya mendekati 1 . Pelepasan zat aktif yang mengikuti persamaan higuchi menunjukkan bahwa jumlah obat yang terlepas sebanding dengan akar waktu. Menurut persamaan higuchi mekanisme pelepasan obat dari granul terjadi secara difusi fickian yang artinya obat keluar dari sediaan karena natrium alginat mengembang (swelling) dan menjadi lapisan

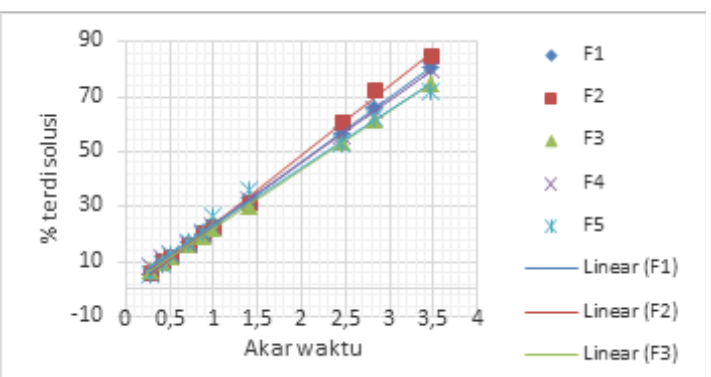

Gambar 6. Model pelepasan Higuchi granul mukoadhesif amoksisilingranul mukoadhesif amoksisilin Keterangan :

Persamaan garis $\mathrm{F} 1 \mathrm{y}=23,38 \mathrm{x}-0,5886 \mathrm{r}=0,9996$

Persamaan garis F2 y $=25,261 \mathrm{x}-1,4363 \mathrm{r}=0,9986$

Persamaan garis F3 y $=21,299 \mathrm{x}+0,9508 \mathrm{r}=0,9998$

Persamaan garis F4 y $=22,69 \mathrm{x}+0,8092 \mathrm{r}=0,9997$

Persamaan garis F5 $\mathrm{y}=20,831 \mathrm{x}+2,4774 \mathrm{r}=0,9949$

gel, melalui lapisan gel ini zat aktif berdifusi keluar dari matriks.

Analisa data. Hasil perhitungan statistik analisa varian dua arah terhadap \% amoksisilin yang terdisolusi pada jam 12 diantara granul F1, F2, F3, F4 dan F5 memberikan nilai sig 0,031<0,05. Hasil perhitungan statistik analisa varian dua arah terhadap hasil uji wash off selama 2 jam diantara granul $F 1$, F2, F3, F4 dan F5 memberikan nilai sig 0,005 <0,05. Sehingga terdapat perbedaan bermakna tiap formula. 


\section{SIMPULAN}

Peningkatan konsentrasi natrium alginat dapat meningkatkan daya mukoadhesif granul amoksisilin pada mukosa lambung tikus tetapi kurang dapat menahan pelepasan obat, formula yang paling baik adalah formula 3 yang mengandung natrium alginat $580 \mathrm{mg}$ dari rentang natrium alginat yang digunakan yaitu $560-620 \mathrm{mg}$.

\section{DAFTAR PUSTAKA}

1. Hoffman A, Qadri BA. 2007. Gastro-Retentive System. Dalam: Encyclopedia of Pharmaceutical Technology third edition volume 1. Hlm. 1850-9.

2. Sweetman, C.S. 2009. Martindale The Complete Drug Reference. $36^{\text {th }}$ ed. Pharmaceutical Press. USA.

3. Sherwood L. 1996. Fisiologi Manusia: dari Sel ke Sistem edisi 2, Terjemahan: Brahm U Pendit. Penerbit Buku Kedokteran EGC. Jakarta. Hlm. 560.

4. Lenaert V, Gurry R. 1999. Bioadhesive Drug Delivery System. Crc Pres, Bocca Raton. Florida. Hlm. 43-63.

5. Rowe R, Sheskey P, Owen S. 2006. Handbook of Pharmaceutical Excipients 5th ed. Pharmaceutical Press. London. Hlm. 389-394, 656-7.
6. Lachman L, Lieberman HA Kanig JL. 1994. Teori dan praktek farmasi industri. Edisi III. Terjemahan: Suyatmi S. UI Press. Jakarta. Hlm. 643, 680, 690, 707

7. Widayanti A. 2011. Pengembangan Formula Sediaan Lepas Lambat Nifedipin Dengan Sistem Mukoadhesif. Dalam: Tesis. Hlm 35

8. Banakar UV.1992. Pharmaceutical Dissolution Testing. Marcell Dekker and Sons inc. New York. Hlm. 139-177

9. Deshpande A, Shah N, Rhodes C, Malick A. 1996. Controlled-Release Drug Delivery Systems for Prolonged Gastric Residence: An overview. Drug Dev. Ind. Pharm. Hlm. 531-9

10. Ririn, Attamimi. F., Nurlina, An Nur. S. 2013. Pengembangan Granul GastromukoadhesifAmoksisilin Menggunakan Gum arab, Tragakan dan Xanthan gum serta uji pelepasan secara in vitro. Dalam: Majalah Farmasi dan Farmakologi, Vol 17, no.1. Hlm. 25-30

11. Departemen Kesehatan RI. 1995. Farmakope Indonesia. Edisi IV. Jakarta: Direktorat Jendral Pengawasan Obat dan Makanan; Hlm. 95-97, 488-489, 1083-4

12. Indrawati T, Agoes G, Yulinah E, Cahyati Y. 2005. Uji daya Lekat Mukoadesif In Vitro beberapa Eksipient Polimer Tunggal dan Kombinasinya Pada Lambung dan Usus Tikus. Dalam: Jurnal Matematika dan Sains Vol 10 No 2. Hlm. 45-51

13. Fudholi A. 2013. Disolusi dan pelepasan obat in vitro. Pustaka pelajar. Yogyakarta. Hlm. 27, 137-54. 